\section{Association Hosts Honors Reception during Annual Meeting}

The Association held its annual Honors Reception on Wednesday, September 2 at the Institute of Contemporary Art in Boston as part of the 1998 Annual Meeting.

At the awards ceremony following the reception, the Association recognized special achievements in the profession. Presentation of the second annual Frank J. Goodnow Awards for Distinguished Service highlighted the evening and were given to Walter E. Beach, Warren E. Miller and Jewel L. Prestage. Named for the Association's first president, the award recognizes individuals who have made outstanding contributions to both the development of the political science profession and the building of the American Political Science Association.

The Association recognized Walter Beach's tireless contributions to the work of the national association and his role in the development of the Southern Political Science Association. Warren Miller was honored not only for his contributions to the study of electoral politics, but also for his 47 years of leadership in the Institute for Social Research and his 27 years of direction of the American National Election Studies. Jewel Prestage's citation highlighted her lifetime commitment to the education of African Americans and her crucial role in the creation of the Ralph Bunche Summer Institute, a critical element in APSA's efforts to increase minority representation in graduate study and political science faculties. Each winner was presented a framed citation and commemorative bowl. The full text of each citation appears in "The Gazette" in this issue of $P S$.

In addition to acknowledging the contributions of the Goodnow Award recipients, the Association recognized outstanding teaching in the discipline. The Association, and Pi Sigma Alpha, which supported the reception, honored political scientists who received campus-wide teaching awards for outstanding teaching during the 1997-98 academic year. More than 100 political

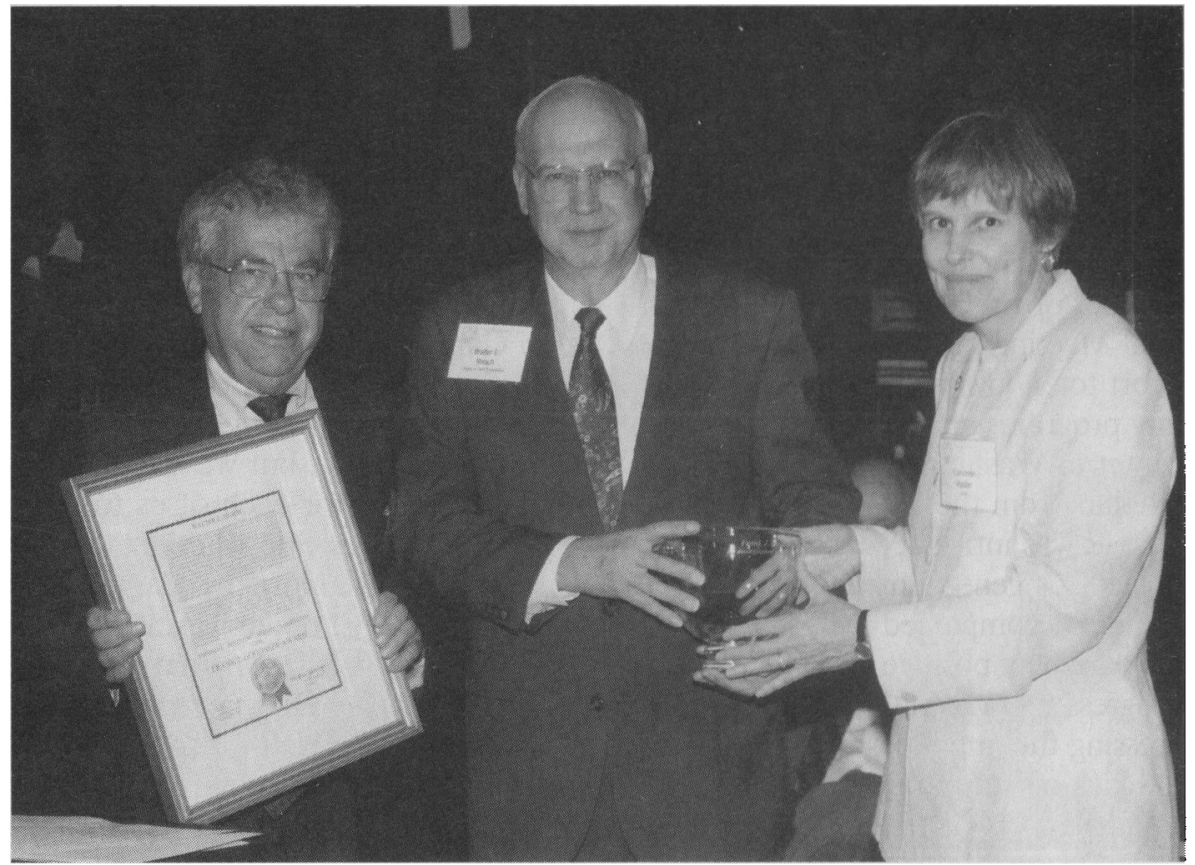

M. Kent Jennings and Catherine E. Rudder present the 1998 Frank J. Goodnow Awards to Walter E. Beach (center) and Jewel L. Prestage (below-center). The Award recognizes individuals who have made outstanding contributions to the development of the political science profession and the building of APSA.

scientists received awards. Kent Jennings recognized the campus-wide teaching award winners who were able to attend the reception. All winners, including those who did not attend the Honors Reception, received a certificate from Pi Sigma Alpha in recognition of their accomplishment. A special section on these winners can be found in this issue of $P S$.

Recognizing political scientists who have developed effective new approaches to teaching in the discipline, the Rowman \& Littlefield Publishing Company, which also helped sponsor the reception, developed the Rowman \& Littlefield Award for Innovative Teaching. L. Sandy Maisel of Colby College, the award selection committee chair, presented the second annual award to Anita Isaacs of Haverford College.

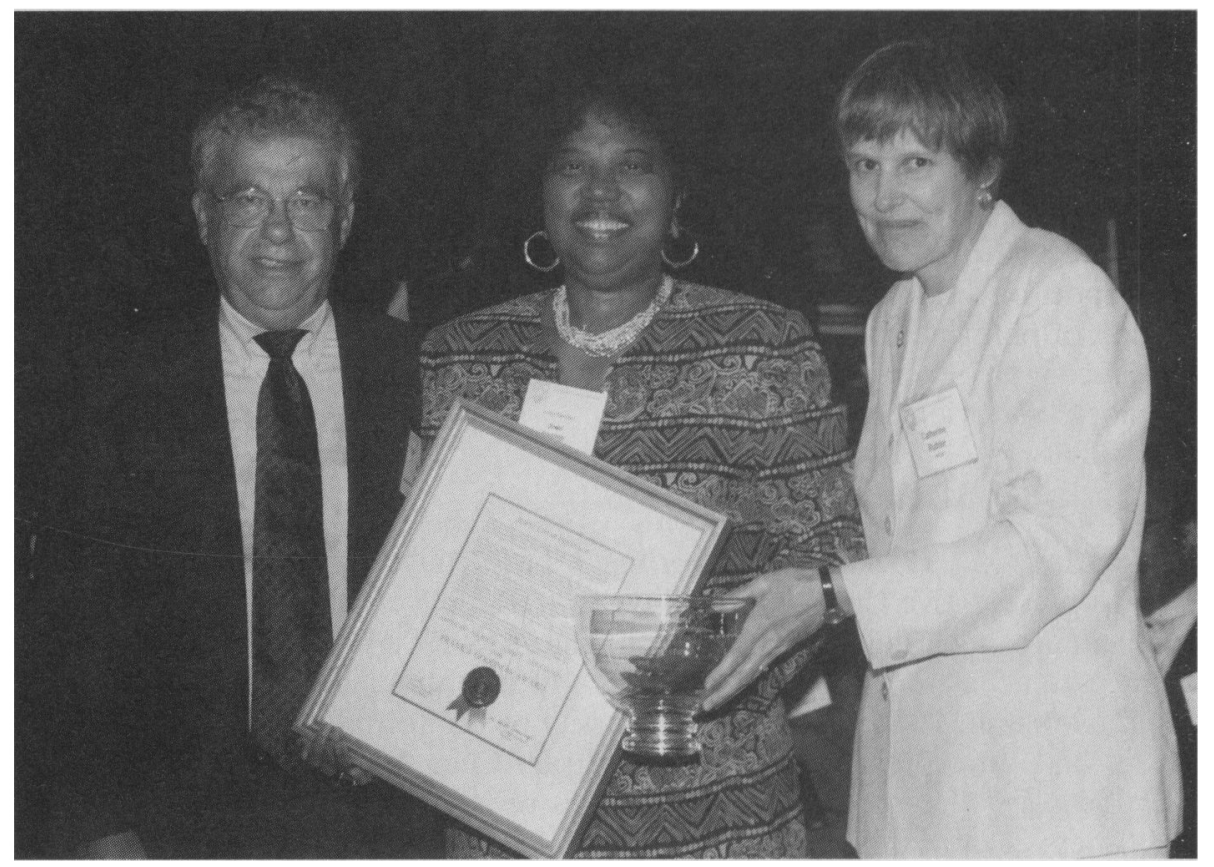




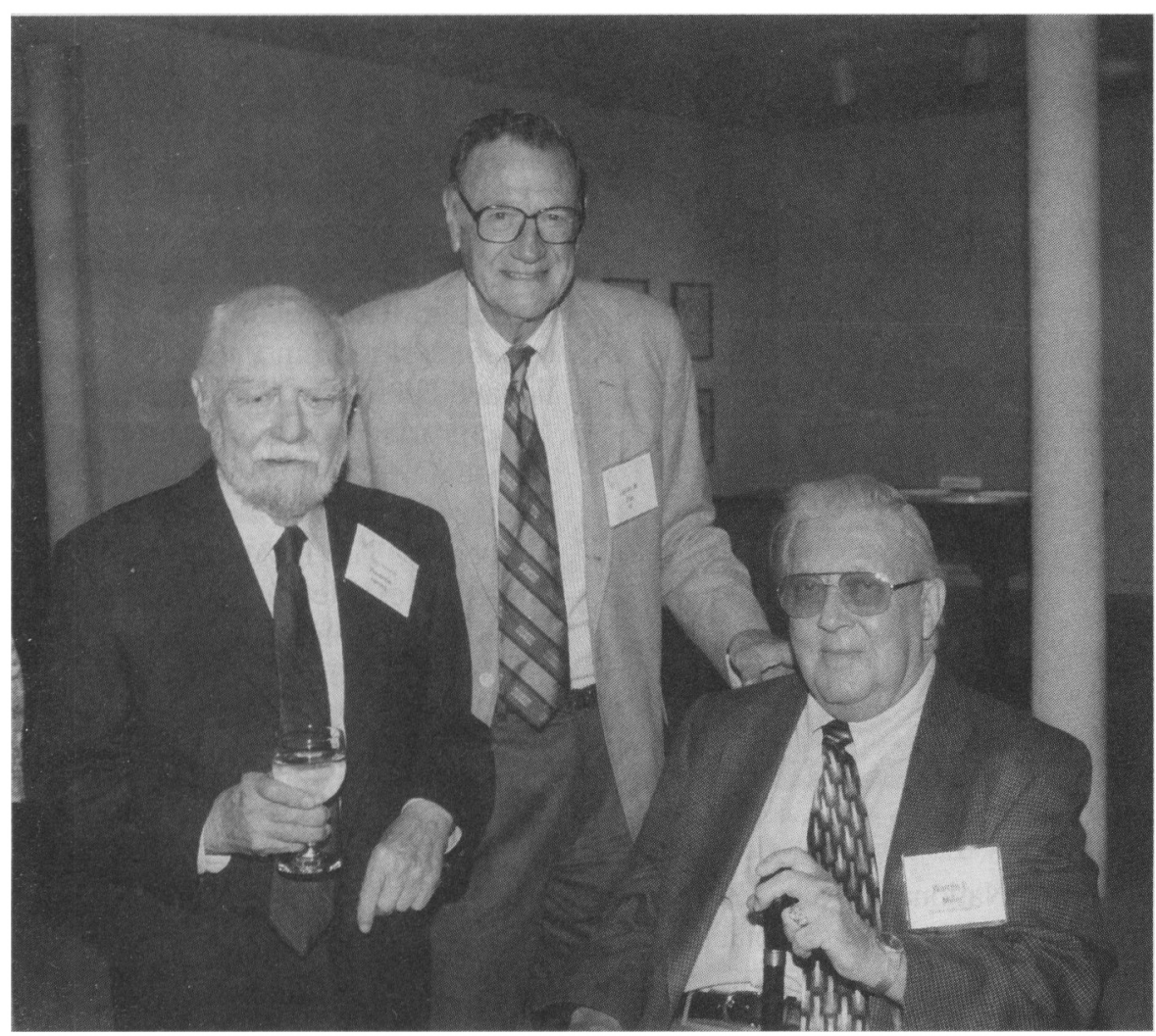

1998 Frank J. Goodnow Award winner and former APSA president Warren E. Miller [R] is joined by Pendleton Herring [L] and Lucian Pye. Miller, Herring, and Pye served as APSA presidents in 1980,1953 , and 1989, respectively.

\section{Association Distributes Annual Awards}

Twenty-one members of the political science community were recognized for their scholarly activity and public service at the 1998 Awards Ceremony, held in conjunction with the Annual Meeting in Boston. Hosted by 1998 Program Chair Virginia Sapiro of the University of Wisconsin, Madison, the major ple-

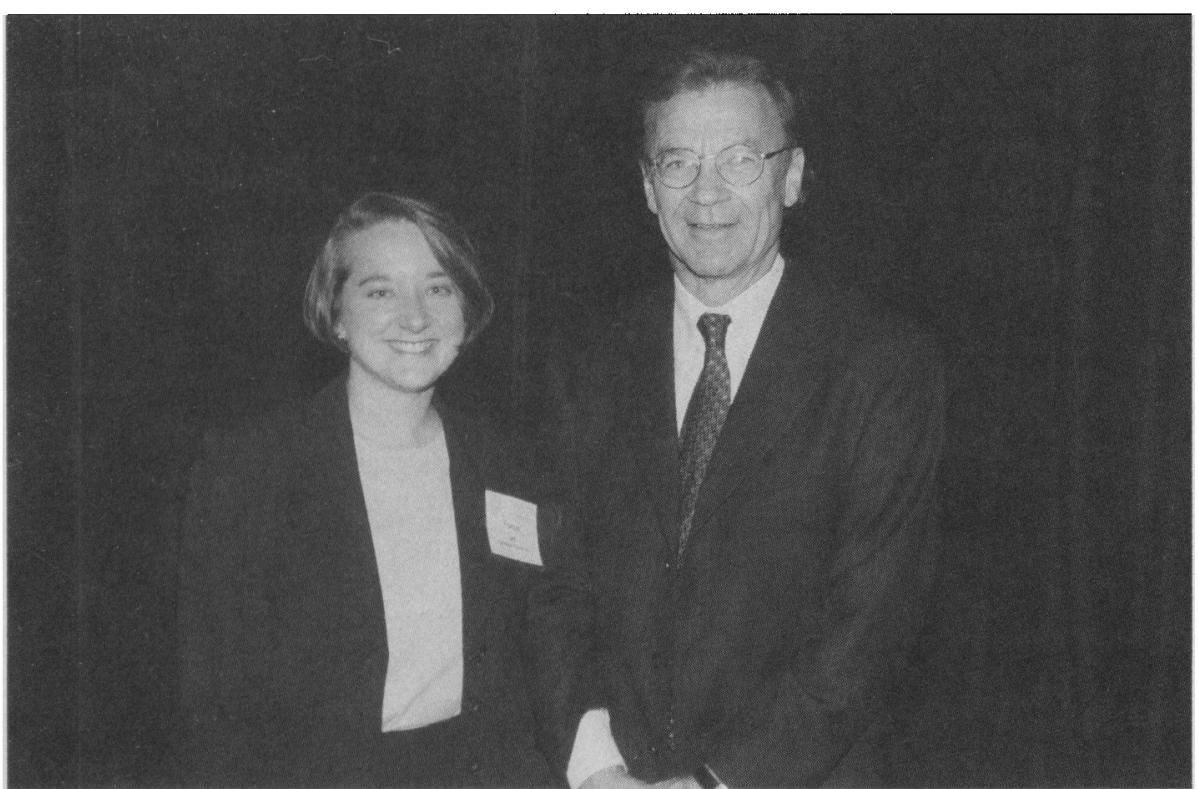

Thomas Patterson [R], Harvard University, chair of the E.E. Schattschneider Award Committee, with 1998 recipient Frances Lee of Case Western Reserve University. The award was presented to Lee for her dissertation, "The Enduring Consequences of the Great Compromise: Senate Apportionment and Congressional Policymaking." nary of the meeting drew nearly 500 attendees and, following the ceremony, featured APSA President M. Kent Jennings' Presidential Address. The Association was especially pleased to honor Representative Lee Hamilton (D-IN) with the $1998 \mathrm{Hu}-$ bert H. Humphrey Award, recognizing his distinguished career in the House of Representatives. Hamilton, who has represented the 9th District of Indiana since 1964, will leave the House following conclusion of the 105th session of Congress to direct the Woodrow Wilson Center for International Scholars. A complete version of the citation honoring Hamilton can be found in the Gazette section of this issue.

Three others also received awards recognizing major contributions to the profession and our understanding and practice of politics. In only its second presentation, the Ithiel De Sola Pool Award was given to W. Lance Bennett of the University of Washington. Pool Committee Chair Marion Just noted in her citation that, like the late Pool, Bennett "has been a fearless scholar, unafraid of tackling tough subjects or cherished icons." As part of the award, Bennett was named the Ithiel de Sola Pool Distinguished Lecturer and delivered his address to a capacity crowd during the meeting.

Eminent scholar Louis C. Gawthrop of the University of Baltimore was presented the John Gaus Award by Committee Chair Lois Recascino Wise. The Gaus prize honors a lifetime of exemplary scholarship in the joint tradition of political science and public administration. In her citation Wise noted that "Gawthrop's professional career is marked by an exemplary contribution of intellectually challenging scholarship in the finest tradition of political science and public administration." With the award, Gawthrop served as the 13th John Gaus Distinguished Lecturer, delivering his lecture on the Friday afternoon of the meeting. Both the Pool and Gaus lectures may be found at the front of this issue of $P S$.

In its annual recognition of exceptional journalism, the Association named Richard Reeves winner of the 1998 Carey McWilliams Award. 